\title{
Effect of Internal and External Factors on Profitability in Sharia Business Units (UUS) PT. Bank Tabungan Negara (Persero) Tbk
}

\section{Wahyudi Gusti Antony, Harlen Harlen, \& Yusni Maulida}

\author{
University of Riau, Pekanbaru, Indonesia
}

*wahyudigustiantony@gmail.com

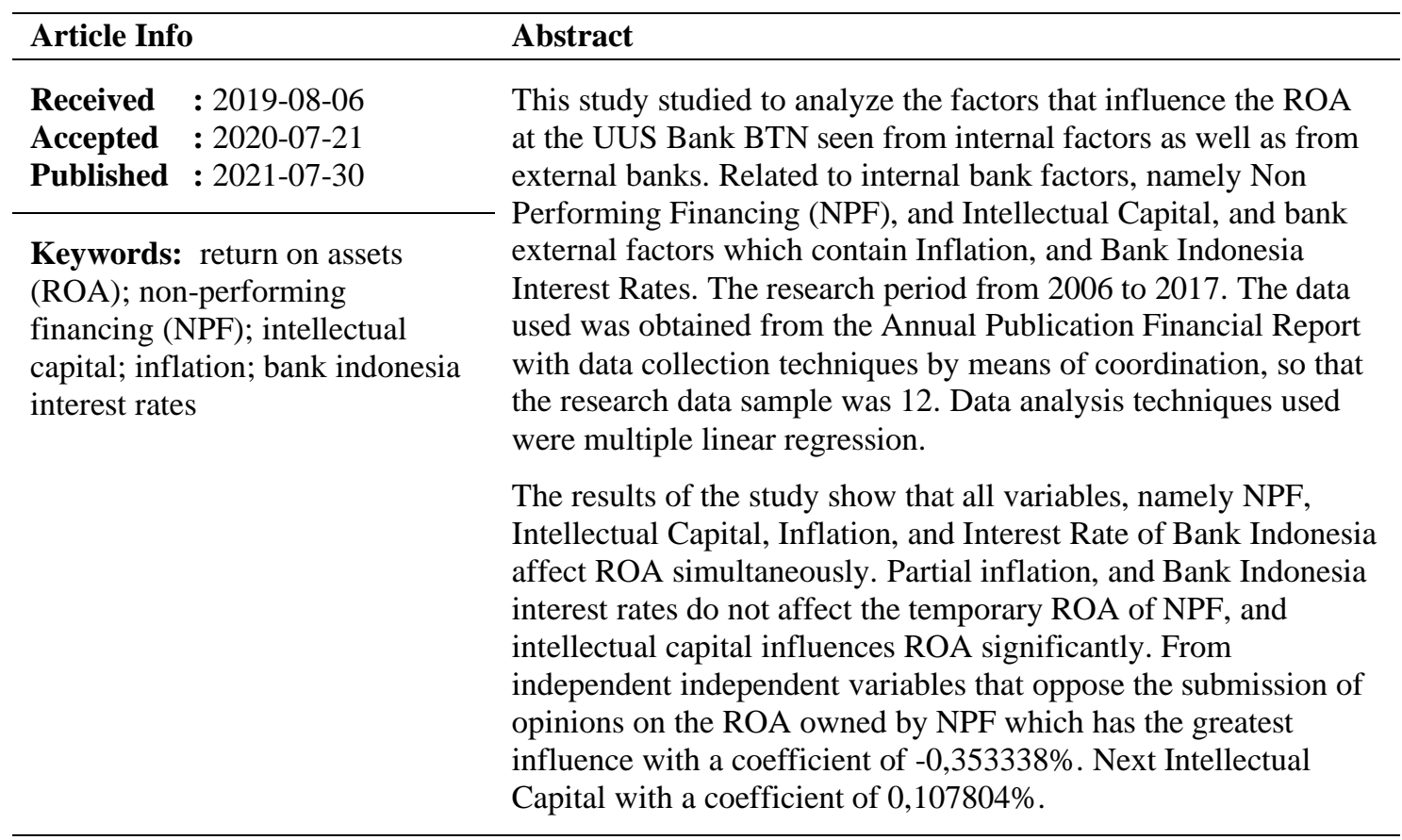

\section{INTRODUCTION}

Profitability or ability to obtain profits is a measure used to assess the extent to which a company is able to generate profits at the level received. As Defri (2012) stated, profitability is the ability of a company to generate profits for a certain period.

Profitability is one of the references in measuring the profitability of a company. With profit, we can find out that a company has run operations efficiently, effectively or not. Efficiency and effectiveness can be known after comparing the profits achieved with assets or capital that have been used to generate profits. As stated by Pandia (2012), said that profitability ratios are a measuring instrument used in measuring the effectiveness of companies earning profits.

Through Bank Indonesia Regulation (PBI) No. 13/1 / PBI / 2011 concerning Evaluation of Soundness Levels of Commercial Banks, Bank Indonesia requires commercial banks to assess the soundness of banks both individually and in consolidation using the Risk approach. One of them is Rentability (Earnings) by using the Return on Assets (ROA) ratio.

Through Bank Indonesia Circular (SEBI) No. 6/23 / DPNP 2004 stipulates that banks with ROA criteria greater than $1.5 \%$ are included in the category "Very Healthy". Likewise the Bank with the ROA Criteria is between $1.25 \%$ and $1.5 \%$ in the "Healthy" category. The ROA criterion between $0.5 \%$ and $1.25 \%$ is in the category "Healthy enough". Banks with ROA criteria are between $0 \%$ and $0.5 \%$ in the category " Unwell". And Banks with ROA criteria are below $0 \%$ (Zero) or minus are included in the category "Not healthy ".

Based on Law No. Article 10 of 1998 concerning Banking, there are 2 types of banks, namely Commercial Banks and People's Credit Banks. The two types of banks in carrying out their business activities are classified into two, namely conventional banks and Islamic banks. 
The fundamental difference between the two lies in the prohibition of interest in Islamic banks as the interest system adopted by conventional banks. So that in carrying out its operations, Islamic banks adhere to a profit sharing system.

From the Banking Statistics data submitted by the Financial Services Authority (OJK), in December 2017 there were 13 Sharia Commercial Banks (BUS), 21 Sharia Business Units (UUS), and 167 Sharia People's Financing Banks (BPRS). The performance of sharia banking assets (total BUS and UUS) continued to increase from 2015 to 2017. This can be seen from the position of sharia banking assets owned in 2015 amounting to $\mathrm{Rp} 272,343$ trillion, up to $\mathrm{Rp}$ 424,181 Trillion in 2017.

On January 16, 2004, the Management of PT Bank Tabungan Negara (Persero) based on the Decree of the Directors No. 14 / DIR / DSYA / 2004 formed the Sharia Division. The establishment of the Sharia Business Unit is also to strengthen the teachings of Bank BTN to make work a part of worship that is not separate from other services. Furthermore, Bank BTN Syariah Business Unit called "UUS Bank BTN" established its motto with the motto "Forward and Prosperous Together". The purpose of establishing Bank BTN UUS is: To meet the needs of the Bank in providing sharia financial services. Support the achievement of the Bank's operating profit target. Improving the resilience of the Bank in the face of changes in the business environment, and providing a balance in meeting the interests of all customers and employees.

In accordance with the purpose of the establishment of UUS Bank BTN, namely in order to support the achievement of Bank BTN's operating profit target, the UUS Bank BTN is also oriented towards achieving profits determined by Management. This can be seen from the performance of UUS Bank BTN profit in 2014 and 2017 which continues to increase sustainably from year to year starting from Rp. 202,137 billion in 2014, then increased to Rp. 260,330 Billion in 2015. It continues to grow to Rp. 377,424 billion in 2016 and in 2017 it increased to Rp. 482,191 billion. When viewed from the achievement of profits each year, information can be obtained that the achievement of UUS Bank BTN profit from the period 2014 to 2017 has increased an average growth of 59.64\% every month.

However, when viewed from the growth of UUS Bank BTN ROA in the period 2015 to 2017, it will be seen that performance ROA has a declining trend compared to the growth of ROA in Islamic banking which tends to increase. In 2015 Bank BTN's ROA UUS was $2.14 \%$, an increase of $8.63 \%$ compared to 2014's ROA of $1.97 \%$. In 2016 Bank BTN ROA UUS amounted to $2.54 \%$, an increase of $18.69 \%$ compared to 2015 ROA of $2.14 \%$. But in 2017 Bank BTN's ROA UUS of $2.46 \%$ decreased by $3.15 \%$ compared to 2016 ROA.

Based on the 2017 Islamic banking statistics report, there is encouraging information for the development of the growth of UUS Bank BTN in the last 3 years, especially in the field of assets. In 2015, 2016, and 2017 the growth of assets of UUS Bank BTN exceeded the growth of assets of UUS and other BUS. Even above the growth of Islamic banking assets in Indonesia. Consecutive developments in the growth of UUS Bank BTN assets for the past 3 years were $18.99 \%$ in 2015. Growth grew to $36.66 \%$ in 2016, and decreased by $29.08 \%$ in 2017.

Based on the above data, Bank BTN's UUS ROA and Assets show that in the same period namely 2014 to 2017 the growth of UUS ROA has a tendency to decline with asset levels which tend to increase even above the average growth of Islamic banking assets. For this reason, it needs to be examined more in the factors that can influence the bank's profitability.

\section{LITERATURE REVIEW}

\section{Profitability}

Profitability describes the ability of a business entity to generate profits by using all of its capital. Shapiro's (1991) statement "profitability ratio measures management measures as indicated by return on sale, assets and owners equity." 
The profitability of a company will influence investors' policies on investments made. The company's ability to generate profits will be able to attract investors to invest their funds in order to expand their business, whereas a low level of profitability will cause investors to withdraw their funds. While for the company itself profitability can be used as an evaluation of the effectiveness of the management of the business entity. According to Brigham (1993) "profitability is the net result of a large number of policies and decisions. The ratio examined thus reveals far some interisting thing about the wry the firm operates, but the profitability ratio show combined objects of liquidity, asset management, and debt management on multiple operations. "

Every business entity will always try to increase its profitability, because the higher the level of profitability of a business entity, the more viable the business entity will be. As revealed by Secchi and Tamagni (2008) "A comparative analysis of two crucial dimensions of firms performance; profitability and productivity, and find independently from a particular sector of activity and from financial conditions, there seems to be a weak market pressure and little behavioral inclination for more efficient and more profitable firms to grow faster.

Dendawijaya 2009 explains that ROA is used to measure bank profitability because Bank Indonesia as a supervisor and banking supervisor prioritizes the profitability of a bank, measured by using assets whose funds are mostly from public savings funds. So it can be concluded that profitability is the ability of a company to generate profits for a certain period.

\section{Signalling Theory}

Signaling Theory or signal theory was developed by Stephen Ross in 1977, stating that the company's executives have better information about their company will be motivated to convey that information to prospective investors so that the company's stock price increases. It is positive in signaling theory where companies that provide good information will distinguish them from companies that do not have "good news", by informing the market about their situation, signals about the good future performance provided by companies whose financial performance is not good will not be trusted by the market (Wolk and Tearney in Dwiyanti, 2010).

Managers are generally motivated to convey good information about their company to the public as quickly as possible, for example through a press conference. But parties outside the company do not know the truth of the information submitted. If the manager can give a convincing signal, the public will be impressed and this will be reflected in the price of securities. So it can be concluded because the existence of asymetric information, giving signals to investors or the public through management decisions becomes very important (Atmaja, 2008).

In signal theory, there is an information asymmetry between the company and the parties concerned. Therefore, companies need to convey useful information through financial statements to interested parties for future investment decisions (Jama'an, 2008). One of the company's performance criteria commonly observed by other investors or stakeholders is the development of profits reported through the income statement. This is the theoretical basis that bank returns or profits are one of the indicators of banking performance.

\section{Return on Assets (ROA)}

ROA is used to measure the ability of bank management to obtain profitability and manage the business efficiency level of the bank as a whole. The greater the value of this ratio shows the level of business profitability of the bank is getting better or healthier (Prasnanugraha, 2007).

ROA shows the effectiveness of the company so that it becomes an important part of the company considering the profits derived from the use of assets can reflect the level of business efficiency of a bank. The greater the ROA, the greater the level of profit achieved by the bank so that it is less likely that the bank will occur in a problematic condition. Within the 
framework of Bank BI's health assessment, it will give a maximum score of 100 in the healthy category if the bank has ROA> 1.5\% (Hasibuan, 2007).

Duraj and Elvana (2015) say that the factors that can affect profitability can be divided into 2 factors, namely internal and external: Determinants of banks profitability can be divided into internal and external factors. Internal factors of bank profitability can be defined as those factors that are influenced by the bank's management of objectives and decisions. Management effects are the results of bank management policies, decisions, objectives and actions in banks operating results, including profitability.

This is reinforced by Machfoeds (1999) who said that the main factors that influence bank profitability according to him are management, namely the entire management of a bank, both covering capital management (CAR), general management, profitability management (BOPO), and liquidity management (LDR ) will ultimately influence and lead to the acquisition of profitability of banking companies.

The development of Islamic banks in Indonesia is experiencing problems because Islamic banks are present in the midst of developments and conventional banking practices that have taken root in people's lives at large. Constraints faced by banks (financial institutions) sharia can not be separated from the unavailability of adequate human resources and legislation. This is one of the factors that can hamper the growth of the national Islamic banking industry.

In contrast to the increasing recognition of intellectual capital in encouraging corporate value and competitive advantage, precise measurement of the company's intellectual capital cannot be determined. For example, Pulic $(1998 ; 1999 ; 2000)$ did not directly measure the company's intellectual capital, but proposed a measure to assess the efficiency of value added as a result of the company's intellectual ability (Value Added Intellectual Coefficient - VAIC TM). The main components of VAIC TM can be seen from company resources, namely physical capital (VACA - value added capital employed), human capital (VAHU - value added human capital), and structural capital (STVA - structural capital value added).

Furthermore, Duraj and Elvana Moci (2015) explained that external determinants of bank profitability are concerned with those factors which are not influenced by specific bank decisions and policies, but events outside influence of the bank.

While external factors (factors that originate from outside the company) include monetary policy, exchange rate fluctuations, and the rate of inflation, interest rate volatility, and financial instrument innovation (Siamat, 2005).

\section{Effect of Non-Performing Financing (NPF) on Return On Assets (ROA)}

According to Muhammad (2005) defines the risk of financing received by a bank is one of the bank's business risks, which is caused by not repaying loans given or investments made by the bank.

The management of financing is very much needed by banks, considering the function of financing as the biggest income contributor for Islamic banks and also the level of financing health (NPF) that influences the achievement of bank profits (Suhada, 2009).

According to Bank Indonesia Circular Letter (SEBI) No. 6 / 23. / DPNP dated 31 May 2004, stated criteria for determining risk profile ranking (NPL / NPF). The following are the details of the NPL ranking criteria which are shown as follows: Banks are included in the Very Healthy category, if they have an NPL of $<2 \%$. Banks are included in the Health category, if they have $2 \% \leq \mathrm{NPL}<5 \%$. Banks are included in the category of Fair Health, if they have $5 \% \leq$ NPL $<8 \%$. Banks are included in the category of Unhealthy if they have $8 \% \leq$ NPL $12 \%$. Banks are included in the Unhealthy category, if they have an NPL $\geq 12 \%$.

NPF is calculated using the following formula:

NPF $=$ Non-Current Financing

Total Financing 


\section{Effect of Intellectual Capital (iB VAICTM) on Return On Assets (ROA)}

The company's goal is to increase profitability and optimize productivity. To achieve this goal the company must be able to manage its intangible assets in the form of intellectual capital in the form of innovation capabilities, information systems, organizational management and human resources which will make added value and competitive advantage. So that by applying knowledge management, the prosperity of the company will depend on the creation of transformation and capitalization of the knowledge itself (Sawarjuwono and Kadir, 2003).

In Indonesia, the intellectual capital phenomenon began to develop especially after the emergence of the Accounting Standards Statement (PSAK) No. 19th revision of 2000 concerning intangible assets. PSAK No. 19 itself describes intangible assets as non-monetary assets that can be identified and do not have physical forms and are owned for use in producing or delivering goods or services, leased to other parties or for administrative purposes (IAI, 2007).

According to Pulic (1998), the main goal in a knowledge-based economy is to create value added. Whereas to be able to create value added, the right size is needed for physical capital (i.e. financial funds) and intellectual potential (represented by employees with all the potential and capabilities inherent in them). Pulic (1998) further states that intellectual ability (which is then called VAICTM) shows how these two resources (physical capital and intellectual potential) are efficiently utilized by the company.

Proper measurement of the company's intellectual capital cannot be determined. For example, Pulic $(1998 ; 1999 ; 2000)$ did not directly measure the company's intellectual capital, but proposed a measure to assess the efficiency of value added as a result of the company's intellectual ability (Value Added Intellectual Coefficient - VAICTM). This method is an analytical procedure designed for stakeholders in controlling and evaluating the added value of the company's total resources, namely capital capital and intellectual capital (www.vaic-on.net). Analysis using this approach is based on assumptions about two of the company's resources. (www.vaicon. net).

The calculation of VAICTM is an addition between the performance of intellectual capital and the performance of physical / financial capital, where intellectual capital consists of human capital and structural capital (Ante pulic, www.vaic-in.net). The calculation includes the calculation of Value added Capital Employed (VACA), which is an indicator of the efficiency of value added physical capital, where this indicator shows how much value added is created from each monetary invested in physical capital and financial capital. Value added Human Capital (VAHU) is an indicator of the efficiency of value added human capital, where this indicator shows how much value added created from each monetary investment in human capital, and Structural Capital Value Added (STVA) is an indicator of the efficiency of value added human capital, where this indicator shows how much value added is created from each monetary invested in human capital. In Islamic banking Intellectual Capital is calculated using Islamic Banking Value Added Intelectual Capital or iB VAICTM. Formulation of the calculation:

$i B-V A I C T M=i B-V A C A+i B-V A H U+i B-S T V A$

1. Formula iB-Value Added (iB-VA) iB-VA = Out - In

Out (Output) represents total income, obtained from:

Net income for sharia activities $=$ the main operating income of sharia activities + other operating income - the rights of third parties to profit sharing and temporary syirkah, and nonoperating income.

In (input) is a business or operational expense and non-operating expenses except employee expenses

The main operating income of sharia activities consists of all components of third party funding disbursement, from Bank Indonesia, and from other banks in Indonesia. Other operating 
income consists of bound investment services, services, income from foreign exchange transactions, correction of PPAP, correction of allowance for write-off transactions. administration, and others. While the rights of third parties to temporary shirkah revenue sharing consist of all third party components not banks, Bank Indonesia, and other banks in Indonesia and outside Indonesia.

Operating / operating expenses except personnel expenses consist of allowance for losses on net earning assets, estimated costs of commitments and contingencies losses, other operating expenses.

2. Formula for calculating iB-Value Added Capital Employed (iB-VACA) is: $i B-V A C A=i B-$ $\mathrm{VA} / \mathrm{CE}$

$\mathrm{CE}=$ Available funds (total equity)

4. Formula for calculating iB-Value Added Human Capital (iB-VAHU) is: $i B-V A H U=i B-V A$ / $\mathrm{HC}$

$\mathrm{HC}=$ Employee expense

5. Formula for calculating iB-Structural Capital Value Added (iB-STVA) is: $i B-S T V A=S C$ / iB-VA

$\mathrm{SC}=\mathrm{iB}-\mathrm{VA}-\mathrm{HC}$

\section{Effects of Inflation on Return On Assets (ROA)}

Inflation is a process of increasing prices in general and continuously related to the market mechanism which can be caused by various factors, among others, increased public consumption, excess liquidity in the market which triggers consumption or even speculation, to include due to the lack of distribution of goods. Can be interpreted as a process of decreasing the value of a currency continuously. Inflation is the process of an event, not the price level.

Inflation is an indicator to see the rate of change, and is considered to occur if the process of price increases takes place continuously and influences each other. The term inflation is also used to mean an increase in money supply which is sometimes seen as the cause of rising prices. There are many ways to measure inflation, the two most commonly used are the CPI and GDP Deflator. Inflation is divided into 4 levels, namely: (1) Light inflation, if the price increase is below $10 \%$ a year. (2) Moderate inflation, if the price increase is between $10 \%-30 \%$ a year. (3) Heavy inlation, if the price increase is between $30 \%-100 \%$ a year. (4) Hyperinflation, if the price increase is above $100 \%$ a year.

Inflation can adversely affect the economy. If there is severe inflation that is uncontrolled (hyperinflation) then the economic situation becomes chaotic and the economy feels sluggish. This resulted in people's interest in saving, or investing and producing reduced. Prices are rising rapidly, people will be overwhelmed to bear and offset the skyrocketing prices of daily necessities. For a company, inflation causes an increase in their production and operational costs so that it ultimately harms the bank itself. Inflation has the potential to hoist credit interest. The increase in loan interest will certainly hinder the growth of credit itself. While income from the credit sector will be small. This affects the profitability of the bank concerned.

\section{Effect of Bank Indonesia Interest Rate (BI Rate) on Return On Assets (ROA)}

BI Rate is one of the mechanisms used by Bank Indonesia to control the stability of the Rupiah. By selling SBIs, Bank Indonesia can absorb the outstanding surplus money.

The interest rate that applies to each SBI sale is determined by the market mechanism based on the auction system. Since the beginning of July 2005, BI has used a "BI rate" mechanism, namely BI announces the target of the SBI interest rate that BI wants for the auction for a certain period. 


\section{Sharia Business Unit PT. Bank Tabungan Negara (Persero) Tbk}

Starting from the changes in banking legislation by the Government of the Republic of Indonesia from the Banking Act No. 7 of 1992 became Law No. 10 of 1998 concerning banking, the world of national banking became more passionate about the presence and boom of Islamic banks. Competition in the banking market has become tighter. Coupled with the issuance of PBI No. 4/1 / PBI / 2002 concerning changes in the business activities of conventional commercial banks into commercial banks based on sharia principles by conventional commercial banks, the number of Islamic banks also increased with the presence of Sharia Business Units (UUS). So the management of PT. Bank Tabungan Negara (Persero), through the BTN Bank restructuring implementation steering committee meeting on December 12,2003 , compiled a work plan and amended the articles of association to open UUS in order to compete in the Islamic banking market.

To anticipate this trend, PT Bank Tabungan Negara (Persero) at the General Meeting of Shareholders on January 16, 2004 was marked by a change in the Articles of Association with deed No. 29 dated 27 October 2004 by Emi Sulistyowati, SH A notary in Jakarta formed a sharia division based on the Decree of the Directors No. 14 / DIR / DSYA / 2004. The establishment of the Sharia Business Unit is also to strengthen the teachings of Bank BTN to make work a part of worship that is not separate from other services. Furthermore, Bank BTN Syariah Business Unit called "UUS Bank BTN" established its motto with the motto "Forward and Prosperous Together".

The purpose of the establishment of UUS Bank BTN is: To meet the needs of the Bank in providing sharia financial services. Support the achievement of the Bank's operating profit target. Improve bank resilience in the face of changes in the business environment. Give a balance in fulfilling the interests of all customers and employees.

On December 15, 2004, Bank BTN received a letter of approval from BI, Letter No. 6/1350 / DPbs concerning BI approval regarding the principle of the BTN Bank Sharia Branch Office (KCS). So this date is officially commemorated as the birthday of BTN Syariah. In synergy through the approval of BI, the KCS Jakarta was opened on February 14, 2005. It was followed on February 25, 2005 with the opening of KCS Bandung and on March 17, 2005 KCS Surabaya was opened on the 4th and April 11th 2005 KCS Yogyakarta and KCS Makassar and in December 2005 the opening of KCS Malang and Solo.

\section{Previous research}

Research on Non-Performing Financing (NPF), Intellectual Capital (iB VAICTM), Inflation, and Bank Indonesia Interest Rates (BI Interest Rate) on Return on Assets (ROA) has been carried out by several previous researchers, as conducted by Gunartin (2015) who studied Islamic and conventional banking in Indonesia for the June 2010-2013 period showed that the NPL had a significant negative effect on ROA. Different research results were obtained by Kartika Wahyu Sukarno and Muhammad Syaichu (2006) who examined Commercial Banks in Indonesia, proving that NPL had a positive and insignificant effect on ROA. Furthermore, the research was conducted by Ubaidillah (2016), who examined Islamic banks in Indonesia and obtained results that NPF did not affect ROA.

Nazif Oskan, Sinan Cakan and Murad Kayacan (2016) conducted a study at Bank Turkey which proved that Intellectual Capital (VAIC) had a significant positive effect on ROA. Different results were obtained by Ousama Abdulrahman Anam and A.H Fatima (2015) who conducted research on Islamic Banking in Indonesia which proved that VAIC had a positive, but not significant, effect on ROA. Zainal Bahri (2016) conducted a study of Islamic Banking in Indonesia which showed that Intellectual Capital (iB VAICTM) had a significant effect on the variable profitability (ROA).

Brunilda Duraj and Elvana Moci (2015) investigating Banking in Albania which produced an inflation rate had a significant negative effect on profitability. The research of 
Muhammad Said and Herni Ali (2017) who research Islamic Banking and produce that Inflation has a positive influence on ROA in Islamic Banking in Indonesia. Furthermore, Andy Setiawan (2017) examines about Islamic banks in Indonesia which show interest rates do not affect ROA. While inflation has no significant negative effect on ROA. Gunartin (2015) who examined Islamic and conventional banking in Indonesia for the June 2010-2013 period showed that the results of inflation and BI interest rates did not significantly influence ROA.

\section{Framework}

Based on the theoretical foundation and previous studies above regarding the relationship between the dependent variable (ROA) and the independent variables (NPF, Intellectual Capital, Inflation, and SBI), then a theoretical framework can be described as presented below:

Theoretical Framework

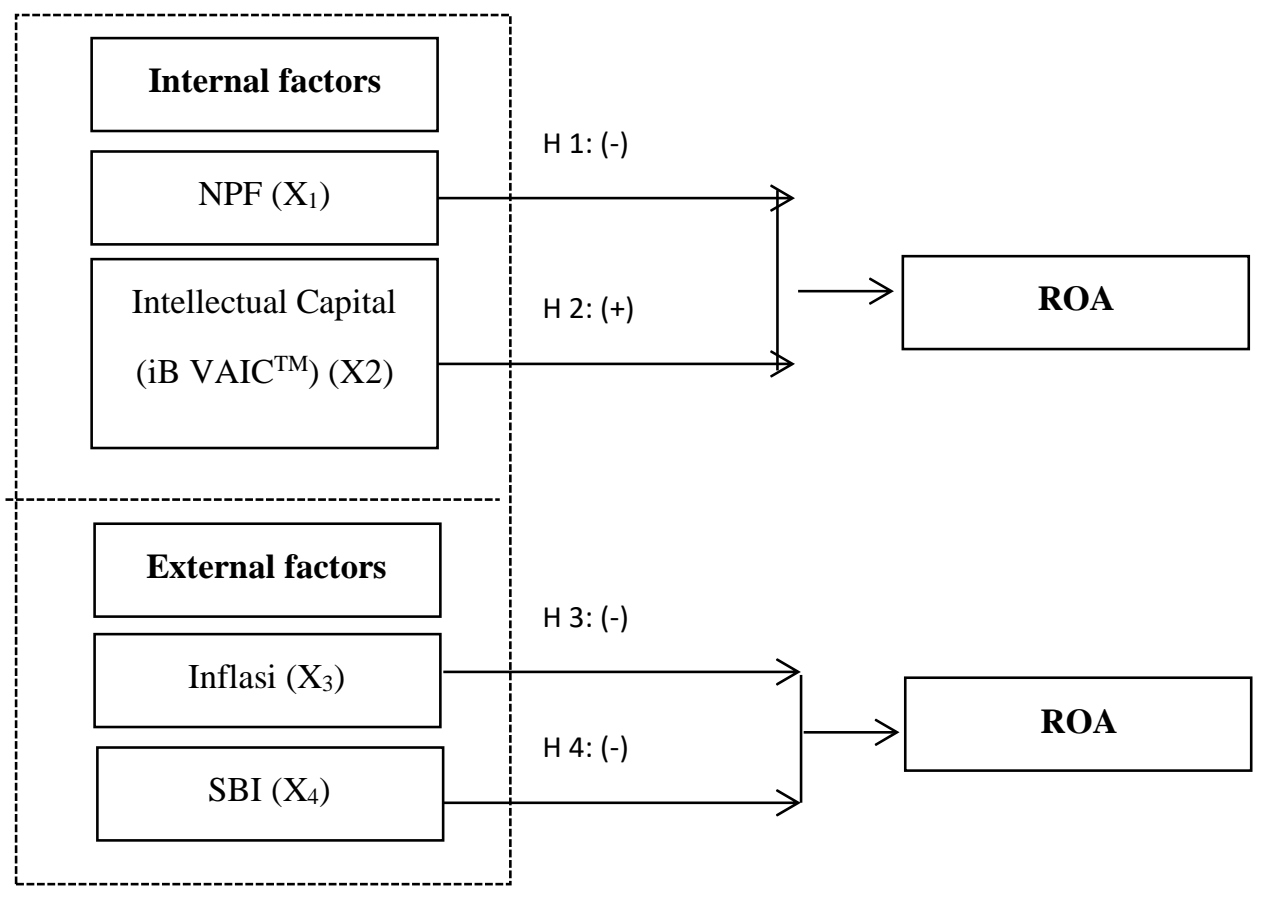

\section{METHODOLOGY}

Data

The object of the study is the Sharia Business Unit (UUS) of PT. State Savings Bank (Persero) Tbk with a period of data analyzed from 2006 to 2017. Data on Return On Assets (ROA), Non Performing Financing (NPF), Intellectual Capital (iB VAIC ${ }^{\mathrm{TM}}$ ), Inflation, and SBI Interest Rates are extracted from the company's annual financial statements.

\section{Methods of Analysis}

Prior to testing the hypotheses, the data were checked to meet the classical assumptions that consists of four issues, normality model, multicollinearity, heteroskedasticity, and autocorrelation. To test the hypotheses, the study uses Multiple linear regression with the equation :

$$
\mathrm{ROA}_{t}=\mathrm{a}+\mathrm{b}_{1} \mathrm{NPF}_{\mathrm{t}}+\mathrm{b}_{2} \mathrm{iBVAIC}_{\mathrm{t}}+\mathrm{b}_{3} \mathrm{IFL}_{\mathrm{t}}+\mathrm{b}_{4} \mathrm{SBI}_{\mathrm{t}}+\mathrm{e}
$$


where ROA is Return On Asset, NPF is Non Performing Financing, iB VAIC is Intellectual Capital, and SBI is the Bank Indonesia Certificate.

$$
\begin{aligned}
\mathrm{t} \text { count }=\frac{\text { regression coefficient } \mathrm{b} 1}{\text { Standard deviation } \mathrm{b} 1} \\
\mathrm{~F} \text { count }=\frac{\mathrm{R} 2 /(\mathrm{k}-1)}{(1-\mathrm{R} 2) /(\mathrm{N}-\mathrm{k})}
\end{aligned}
$$

\section{RESULT AND DISCUSSION}

\section{Overview of Research Objects}

Table 1 : Development of ROA, NPF, iB VAIC TM UUS, Bank BTN, and Inflation, and SBI for the period 2006-2017

\begin{tabular}{|c|c|c|c|c|c|}
\hline Tahun & ROA & NPF & iB VAIC $^{\text {TM }}$ & Inflasi $^{\text {SBI }}$ \\
\hline $\mathbf{2 0 0 6}$ & 1,78 & 1,16 & 1,64 & 6,60 & 9,75 \\
\hline $\mathbf{2 0 0 7}$ & 1,89 & 0,88 & 1,70 & 6,59 & 8,00 \\
\hline $\mathbf{2 0 0 8}$ & 1,80 & 0,41 & 1,89 & 11,06 & 9,25 \\
\hline $\mathbf{2 0 0 9}$ & 1,47 & 3,35 & 3,29 & 2,78 & 6,50 \\
\hline $\mathbf{2 0 1 0}$ & 1,04 & 4,90 & 7,02 & 6,96 & 6,50 \\
\hline $\mathbf{2 0 1 1}$ & 1,52 & 3,42 & 3,89 & 3,79 & 6,00 \\
\hline $\mathbf{2 0 1 2}$ & 1,83 & 2,38 & 4,36 & 4,30 & 5,75 \\
\hline $\mathbf{2 0 1 3}$ & 2,40 & 1,16 & 5,03 & 8,38 & 7,50 \\
\hline $\mathbf{2 0 1 4}$ & 1,97 & 2,06 & 5,44 & 8,36 & 7,75 \\
\hline $\mathbf{2 0 1 5}$ & 2,14 & 1,66 & 4,88 & 3,35 & 7,50 \\
\hline $\mathbf{2 0 1 6}$ & 2,54 & 1,01 & 6,30 & 3,02 & 6,50 \\
\hline $\mathbf{2 0 1 7}$ & $\mathbf{2 , 4 6}$ & $\mathbf{0 , 9 5}$ & 6,26 & 3,61 & 6,50 \\
\hline Tertinggi & $\mathbf{2 , 5 4}$ & $\mathbf{4 , 9 0}$ & $\mathbf{7 , 0 2}$ & $\mathbf{1 1 , 0 6}$ & $\mathbf{9 , 7 5}$ \\
\hline Terendah & $\mathbf{1 , 0 4}$ & $\mathbf{0 , 4 1}$ & $\mathbf{1 , 6 4}$ & $\mathbf{2 , 7 8}$ & $\mathbf{5 , 7 5}$ \\
\hline Rata-Rata & $\mathbf{1 , 9 2}$ & $\mathbf{1 , 9 5}$ & $\mathbf{4 , 3 1}$ & $\mathbf{5 , 7 3}$ & $\mathbf{7 , 2 9}$ \\
\hline
\end{tabular}

Source: www.btn.co.id, data is processed

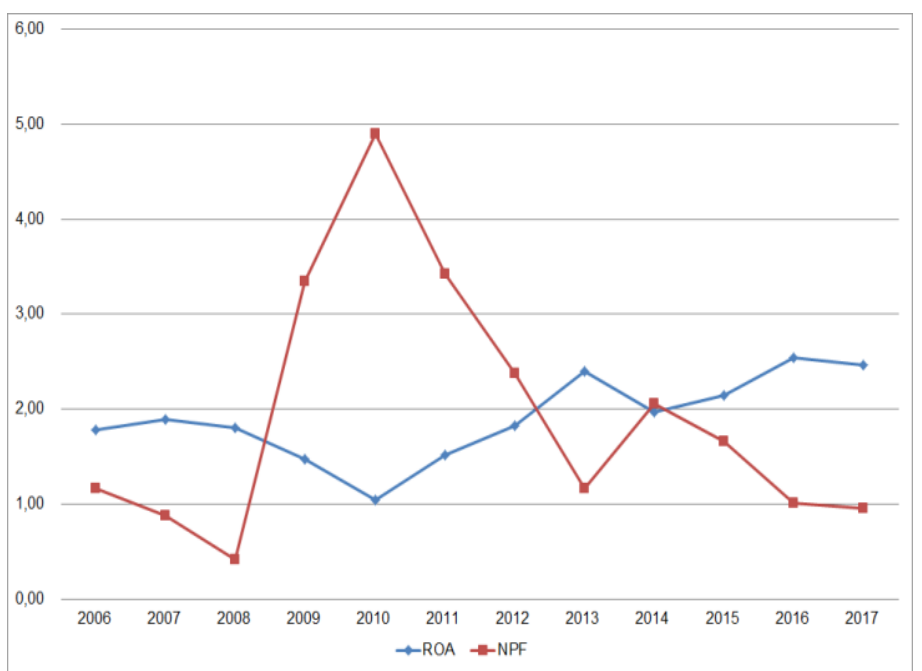

Graph 1 : Dynamics of the Effect of NPF on Bank BTN ROA UUS for the Period 2006-2017 
Effect of Internal and External Factors on Profitability in Sharia Business Units (UUS) PT. Bank Tabungan Negara (Persero) Tbk

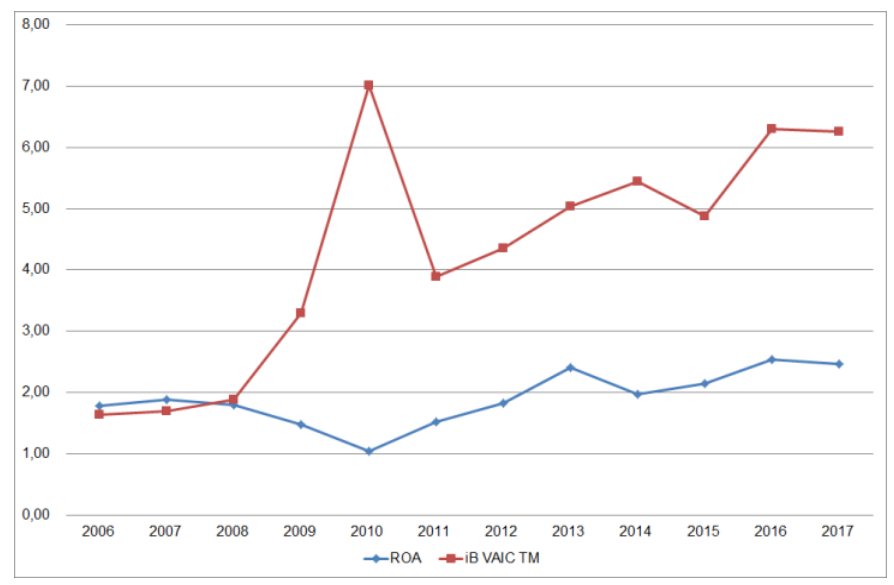

Graph 2 : Dynamics of the Effect of Intellectual Capital (iN VAIC) on Bank BTN ROA UUS for the Period 2006-2017

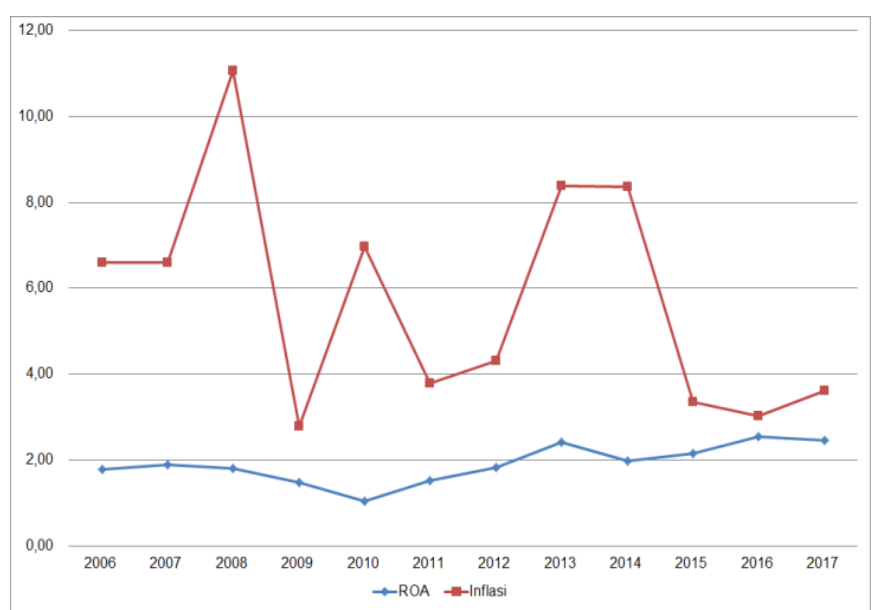

Graph 3 : Dynamics of Inflation Influence on Bank BTN ROA UUS for the Period 2006-2017

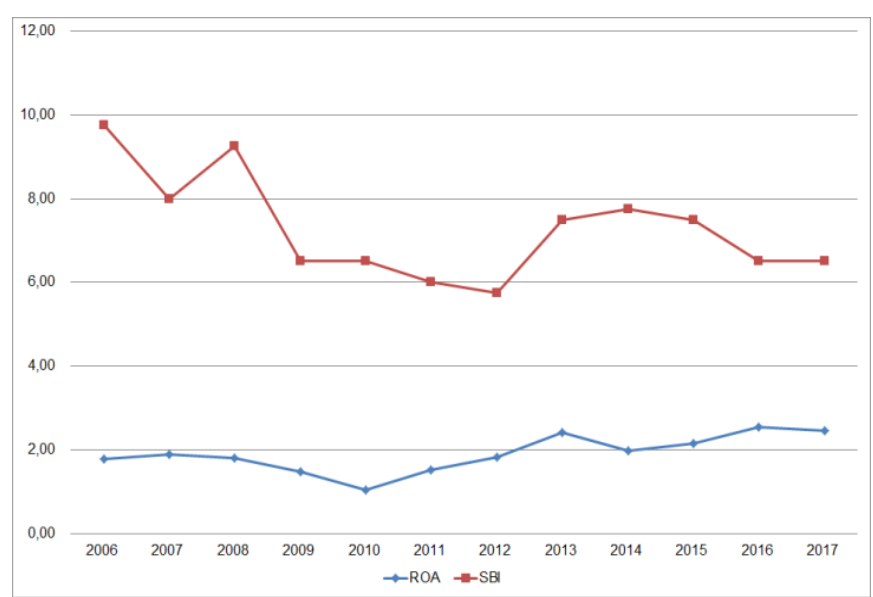

Graph 4 : Dynamics of Influence of SBIs on Bank BTN ROU UUS for the Period of 2006-2017 


\section{Descriptive Research Variable Statistics}

Table 2 shows the descriptive statistics of variables examined in this study:

Table 2 : Description of Research Variables

\begin{tabular}{lccccc}
\hline \hline & ROA & NPF & IB_VAIC_TM & INFLASI & SBI \\
\hline \hline Mean & 1.903333 & 1.945000 & 4.308333 & 5.733333 & 7.291667 \\
Median & 1.860000 & 1.410000 & 4.620000 & 5.445000 & 7.000000 \\
Maximum & 2.540000 & 4.900000 & 7.020000 & 11.06000 & 9.750000 \\
Minimum & 1.040000 & 0.410000 & 1.640000 & 2.780000 & 5.750000 \\
Std. Dev. & 0.440441 & 1.340031 & 1.864588 & 2.652126 & 1.251514 \\
Skewness & -0.242178 & 0.956972 & -0.215765 & 0.569025 & 0.728181 \\
Kurtosis & 2.469637 & 2.899205 & 1.793719 & 2.217925 & 2.487517 \\
& & & & & \\
Jarque-Bera & 0.257943 & 1.836670 & 0.820666 & 0.953400 & 1.191815 \\
Probability & 0.878999 & 0.399183 & 0.663429 & 0.620829 & 0.551062 \\
& & & & & \\
Sum & 22.84000 & 23.34000 & 51.70000 & 68.80000 & 87.50000 \\
Sum Sq. Dev. & 2.133867 & 19.75250 & 38.24357 & 77.37147 & 17.22917 \\
& & & & & \\
Observations & 12 & 12 & 12 & 12 & 12
\end{tabular}

Source: www.btn.co.id, data is processed

The average data ratio of Bank BTN ROA UUS is $1.90 \%$. This shows that during the study period, it can be explained statistically that the UUS Bank BTN profit rate on its assets is included in the "very healthy" category, according to the ranking criteria set by Bank Indonesia.

The NPF ratio is obtained by an average of $1.95 \%$. Thus, it can be concluded that statistically, during the study period, the level of UUS Bank BTN NPF was classified as "very healthy" as determined by BI, which was below $2 \%$.

The value of Intelectual Capital obtained an average of $4.31 \%$ with the lowest data of $1.64 \%$, namely in the period of 2006 and the highest of $7.02 \%$, namely in the period of 2010 . Conditions fluctuated with a tendency to increase every year.

Inflation value obtained an average of $5.7 \%$ with the lowest data of $2.78 \%$, namely in the period 2009 and the highest $11.06 \%$, namely in the period of 2008 . Thus it can be concluded that statistically, during the study period, the inflation rate happening in Indonesia has a fluctuating tendency.

Likewise, the SBI interest rate information obtained an average of $7.29 \%$ with the lowest data of 5.75\%, namely in the period of 2012 and the highest of $9.75 \%$, namely in the period of 2006. Thus it can be concluded that statistically, as long as during the study period, SBI interest rates in Indonesia had a fluctuating tendency.

Furthermore, to see whether or not there are data experiencing outliers in the research data, descriptive statistics are used by comparing the mean and standard deviations. If the standard deviation is greater than the mean, then there are outlier data in the study. Based on the five variables above do not experience outlier data because the mean is greater than the standard deviation. Next is the classic assumption test or prerequisite test before conducting the $\mathrm{F}$ test and $\mathrm{t}$ test.

\section{Graph 5: Histogram Graph}
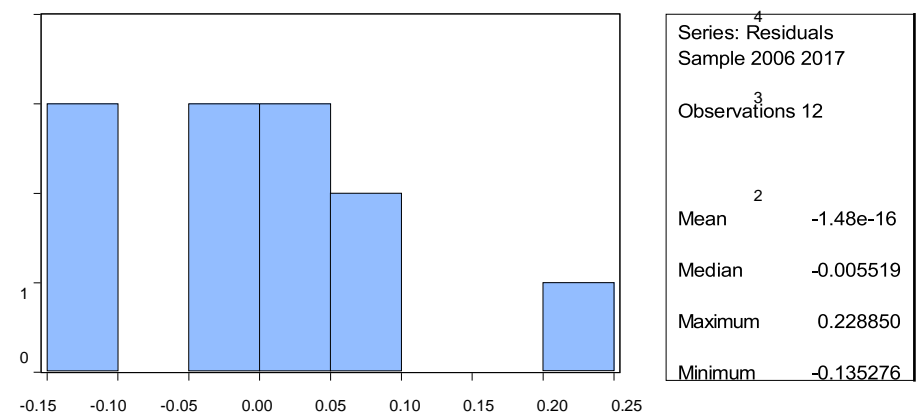

Source: Secondary data processed 
Effect of Internal and External Factors on Profitability in Sharia Business Units (UUS) PT.

Bank Tabungan Negara (Persero) Tbk

Table 3: Multicollinearity Test Results

Variance Inflation Factors

Date: 04/11/19 Time: 18:13

Sample: 20062017

Included observations: 12

\begin{tabular}{cccc}
\hline \hline Variable & $\begin{array}{c}\text { Coefficient } \\
\text { Variance }\end{array}$ & $\begin{array}{c}\text { Uncentered } \\
\text { VIF }\end{array}$ & $\begin{array}{c}\text { Centered } \\
\text { VIF }\end{array}$ \\
\hline \hline C & 0.228149 & 167.8488 & NA \\
NPF & 0.001248 & 4.986477 & 1.511853 \\
IB_VAIC_TM & 0.000753 & 12.05321 & 1.766227 \\
INFLASI & 0.000412 & 11.91140 & 1.953273 \\
SBI & 0.003468 & 139.2975 & 3.662692 \\
\hline \hline
\end{tabular}

Source: Secondary Data processed

Table 4: Autocorrelation Test Results

Breusch-Godfrey Serial Correlation LM Test:

Null hypothesis: No serial correlation at up to 2 lags

\begin{tabular}{llll}
\hline \hline & & & \\
F-statistic & 0.334006 & Prob. F(2,5) & 0.7309 \\
Obs*R-squared & 1.414279 & Prob. Chi-Square(2) & 0.4931 \\
\hline
\end{tabular}

Test Equation:

Dependent Variable: RESID

Method: Least Squares

Date: 04/11/19 Time: 18:25

Sample: 20062017

Included observations: 12

Presample missing value lagged residuals set to zero.

\begin{tabular}{crrrr}
\hline \hline \multicolumn{1}{c}{ Variable } & Coefficient & Std. Error & t-Statistic & Prob. \\
\hline \hline C & 0.089334 & 0.583818 & 0.153016 & 0.8844 \\
NPF & 0.016562 & 0.044320 & 0.373688 & 0.7240 \\
IB_VAIC_TM & -0.008286 & 0.036981 & -0.224064 & 0.8316 \\
INFLASI & 0.009934 & 0.025652 & 0.387256 & 0.7145 \\
SBI & -0.020367 & 0.072711 & -0.280104 & 0.7906 \\
RESID(-1) & 0.036027 & 0.534146 & 0.067448 & 0.9488 \\
RESID(-2) & 0.493246 & 0.607143 & 0.812405 & 0.4535 \\
\hline \hline & & & & \\
R-squared & 0.117857 & Mean dependent var & $-9.58 \mathrm{E}-16$ \\
Adjusted R-squared & -0.940716 & S.D. dependent var & 0.101881 \\
S.E. of regression & 0.141930 & Akaike info criterion & -0.775767 \\
Sum squared resid & 0.100721 & Schwarz criterion & -0.492904 \\
Log likelihood & 11.65460 & Hannan-Quinn criter. & -0.880492 \\
F-statistic & 0.111335 & Durbin-Watson stat & 1.899599 \\
Prob(F-statistic) & 0.990647 & & & \\
\hline \hline
\end{tabular}

Source: Secondary Data processed 


\section{Heteroscedasticity Test}

A good regression model is homokedasticity or heterocedasticity does not occur. In EViews, the Heterocedasticity Test can use the Glejser Test as shown in the following table.

Table 5: Heteroscedasticity Test Results

\begin{tabular}{llll} 
Heteroskedasticity Test: Breusch-Pagan-Godfrey & \\
Null hypothesis: Homoskedasticity & & \\
\hline \hline & & & \\
F-statistic & 1.563573 & Prob. F(4,7) & 0.2839 \\
Obs ${ }^{*}$-squared & 5.662430 & Prob. Chi-Square(4) & 0.2258 \\
Scaled explained SS & 2.096858 & Prob. Chi-Square(4) & 0.7179 \\
\hline \hline
\end{tabular}

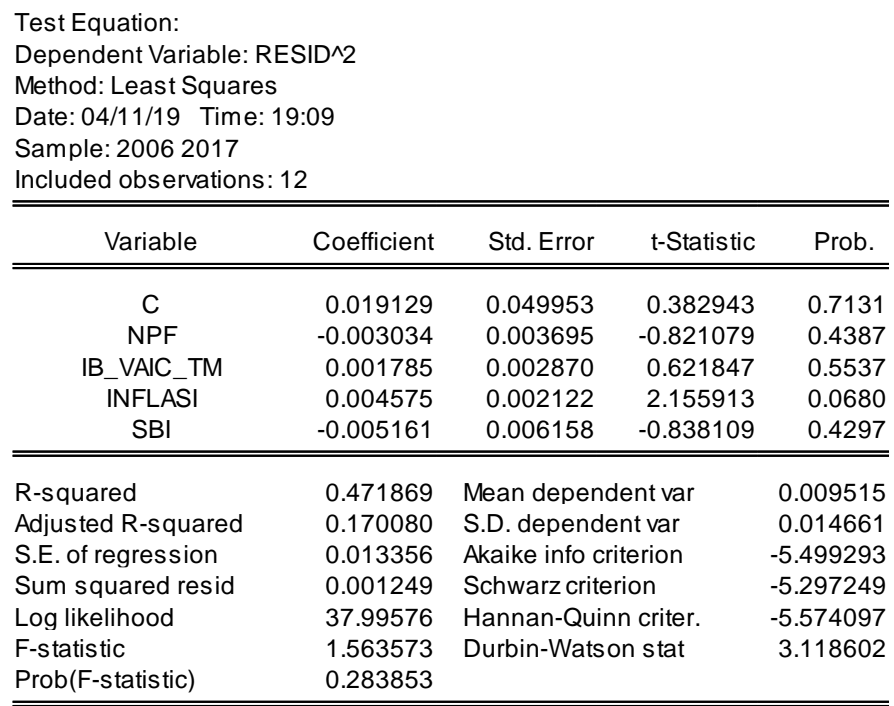

Source: Secondary Data processed

\section{Classical Assumption Tests}

The normality test of the absolute residual show that the distribution is normal. The model is free from multicollinearity as the VIF values are all less than 10 . There are no symptoms of autocorrelation because of the Probability of the Chi-Square is greater than 0.05 . The model is free from Heteroscedasticity as the probability of the Chi-Square is greater than 0.05 .

\section{Results of Multiple Regression Transformation Analysis}

Table 3 shows the results of regression analysis. As shown in Table 3, NPF has a negative and significant effect on the ROA. The iB VAIC ${ }^{\mathrm{TM}}$ has a positive and significant effect on the ROA. Inflation and SBI do not have significant effect on ROA.

Table 6: Test Results t

\begin{tabular}{crrrr}
\hline \hline Variable & Coefficient & Std. Error & t-Statistic & Prob. \\
\hline \hline C & 2.643902 & 0.477649 & 5.535234 & 0.0009 \\
NPF & -0.353338 & 0.035333 & -10.00015 & 0.0000 \\
IB_VAIC_TM & 0.107804 & 0.027446 & 3.927789 & 0.0057 \\
INFLASI & -0.029224 & 0.020292 & -1.440142 & 0.1930 \\
SBI & -0.048031 & 0.058886 & -0.815673 & 0.4416 \\
\hline \hline
\end{tabular}


Table 7: F Test Results

\begin{tabular}{lllr}
\hline \hline R-squared & 0.946493 & Mean dependent var & 1.903333 \\
Adjusted R-squared & 0.915917 & S.D. dependent var & 0.440441 \\
S.E. of regression & 0.127715 & Akaike info criterion & -0.983699 \\
Sum squared resid & 0.114177 & Schwarz criterion & -0.781655 \\
Log likelihood & 10.90220 & Hannan-Quinn criter. & -1.058503 \\
F-statistic & 30.95587 & Durbin-Watson stat & 1.954910 \\
Prob(F-statistic) & 0.000153 & & \\
\hline \hline
\end{tabular}

Source: Secondary Data processed

\section{DISCUSSION}

\section{Effect of Non-Performing Financing (NPF) on Return on Assets (ROA).}

Non-Performing Financing (NPF) has a significant negative effect on Return On Assets (ROA). That is, the higher the NPF, the smaller the ROA and vice versa (Sutojo, 2000). NPF is inversely proportional to ROA, which means that the lower the level of non-performing loans (loss) of a bank, the higher the profitability.

Poor quality of financing will cause difficulties in returning financing. Especially if the amount is large enough to affect the performance of the UUS Bank BTN. Poor quality of financing will increase risk, especially if the provision of financing is done by not using the principle of prudence (prudential banking) and expansion in the provision of financing that is less controlled so that the bank will bear greater risks. The risk is in the form of difficulties in returning the financing by the debtor, which if the amount is large enough can affect the performance of the UUS Bank BTN. Much of the disbursed financing does not provide results.

Banks that are undermined by problem loans will decrease their profitability as indicated by ROA, which becomes a benchmark for bank profitability, which will also decrease (Sutojo, 2000). The three negative impacts of problem loans are as follows: (1) Reducing business profitability. (2) Increase the burden of operational costs. (3) Reducing the percentage of Capital Adequacy Ratio (CAR). The results of this study support the results of research by Mawardi (2005) which states that NPF has a significant negative effect on ROA.

\section{Effect of Intellectual Capital (iB VAIC ${ }^{\mathrm{TM}}$ ) on Return on Assets (ROA).}

The results of this study indicate that Intellectual Capital has a significant positive effect on ROA. The higher the value of Intellectual Capital held by UUS Bank BTN, the more it will have an effect on increasing ROA UUS Bank BTN, and vice versa. The existence of intellectual capital values, UUS Bank BTN will get additional profits or the establishment of business processes and provide companies with more value than competitors or other companies (Puspitasari, 2011).

Susanto (2007) states that there are two things to achieve competitive advantage and create value added for the company. First, having excellence in the resources they have, both tangible assets and intangible assets. Second, is the ability to effectively manage these resources. So with these 2 things Bank BTN's UUS can be superior and compete with other competitor banks not only against Islamic banking but also other conventional banks.

The same thing was conveyed by Madhani (2009), in order to be able to provide competitive advantage and sustainable performance these resources must be valuable, scarce, unique and irreplaceable. So that these resources are able to manage intellectual capital well and will create competitive advantage compared to its competitors.

Effect of Inflation on Return on Assets (ROA).

Inflation has a negative effect on ROA but is not significant. This shows that even though inflation has increased, the profits obtained by Islamic banks have not decreased significantly 
and vice versa. The reason for explaining the above conditions is that basically high inflation reflects an increase in goods which makes the value of circulation of money reduced due to rising prices. This shows that inflation does not significantly reduce the collection of public funds in the form of demand deposits, deposits and savings accounts at the UUS Bank BTN. This result suggests that there is little resistance to UUS Bank BTN against inflation.

\section{Effect of Bank Indonesia Interest Rate (SBI) on Return on Assets (ROA).}

BI Rate has a negative effect on ROA but is not significant. This shows that even though Bank Indonesia interest rates have increased, the BTA ROA of Bank BTN has not experienced a significant decline. Islamic banking does not use the interest system in carrying out its operations but with a profit sharing system. Whereas SBI here is a one-month interest rate announced by Bank Indonesia periodically which serves as a signal of monetary policy (Kasmir, 2008). In addition, this proves that: (a) the UUS Customer of Bank BTN has customers who are relatively loyal to the bank and tend toput forward on sharia principles with a small amount of application of the principle of obtaining interest as usury. (b) Products of deposits with mudharabah contracts represent deposits in which funds are deposited and can be taken within a certain period of time. Thus customers who enter deposits must wait several periods to be able to take their deposits so that the effect of short-term interest rates does not seem to change the mudharabah deposits much.

Therefore, it can be concluded that external factors (in this case inflation and SBI) do not have a significant effect on the BTA ROA of Bank BTU. That is, Bank BTN ROA UUS is not affected by inflation and SBI, but is influenced by other variables outside the model in this study. Macro factors as external factors that influence a company's profitability include: BI interest rates, inflation rates, tax regulations, government policies, foreign exchange rates, foreign loan interest rates, and international economic conditions (Aisyah, 2008). Other external factors that might influence profitability are supported by the results of Syafrida's (2011) research which states that GDP has a significant effect on profitability.

\section{Effect of Non-Performing Financing (NPF), Intellectual Capital (iB VAICTM), Inflation, and SBI Interest Rate, Against Return On Assets (ROA).}

Simultaneously it can be seen that CAR, BOPO, NPF, Intellectual Capital (iB VAICTM), Inflation, and SBI Interest Rate have a significant effect on ROA. This means that the management of UUS Bank BTN can pay attention to these variables with the aim of improving the bank's financial performance so that it is always included in the category of healthy banks so that the public and investors choose to conduct banking transactions and invest in these banks.

\section{CONCLUSION}

This study tries to examine how the effect of Non-Performing Financing (NPF), Intellectual Capital (iB VAICTM), Inflation, and SBI Interest Rate, on Return On Assets (ROA). Based on the results of multiple regression analysis shows that most of the proposed hypotheses are rejected (in the sense that there is no significant effect between the independent variables on the dependent variable). The results of the analysis are as follows:

NPF in this study statistically had a significant negative effect on ROA. In this study, Bank BTN's UUS NPF is classified as low with a "very healthy" category set by $\mathrm{BI}$, which is below $2 \%$.

Intellectual Capital has a significant positive effect on ROA. Thus the level of Intellectual Capital banks influences the bank's financial performance. The higher the value of Intellectual Capital, the higher the level of employee productivity. With the greater level of productivity, it should increase the UUS profit of Bank BTN

The results showed that inflation did not have a significant effect on ROA. That is, Bank BTN ROA UUS is not affected by inflation but is influenced by other variables 
outside the model. The chart shows that inflation is relatively volatile in the period 2006-2017 with a very elastic downward trend approaching stagnation. While the BTN ROA of Bank BTN fluctuates with an upward trend in elastic (sloping) so that these two variables are indeed not related. In other words, the rise and fall of inflation does not affect the profitability of UUS Bank BTN.

The results of the analysis in this study show that BI Rate (SBI) has no significant effect on the profitability of UUS Bank BTN. In other words, SBI does not affect the increase or decrease in profitability. The results of this study indicate that interest rates (macro factors) do not affect profitability. Islamic banking does not use the interest system in carrying out its operations but with a profit sharing system. While SBI here is a one-month interest rate announced by Bank Indonesia.

Of the four independent variables tested for their influence on the dependent variable (in this case ROA), it is known that the independent variable NPF has the greatest influence from the other four variables (two non-significant variables), namely with a coefficient of $-0.353338 \%$. The minus sign (-) indicates that the NPF has an inverse relationship to ROA. Each increase in the NPF ratio of $1 \%$ will result in a decrease in the ROA ratio of $0.353338 \%$. Likewise vice versa if the NPF ratio falls by $1 \%$, it will result in an increase in the ROA ratio of $0,353338 \%$.

\section{Suggestion}

This study still has several limitations from the amount of data that is only used for 12 years from the annual financial statements of UUS Bank BTN. Based on some limitations of the research that has been disclosed, the authors provide several suggestions relating to the discussions that have been carried out previously as follows:

1. For Management of UUS Bank BTN

a. It is necessary to know and realize the importance of intellectual capital because it is proven to positively affect the financial performance of the Bank's UUS.

b. Suppress the NPF level by improving the quality of financing problems so that the risk of bad credit can be reduced.

c. Improve product variants and socialize to the public so that their insight into sharia also increases.

2. For investors

Must know and pay attention to the company's intellectual capital as a consideration in investing. Because this has proved that intellectual capital can positively affect the company's financial performance.

2. For further researchers

It is better to use a larger range of years so that the significance of the influence of intellectual capital can be more clearly seen. And using a broader object, and the company studied is not only the UUS Bank BTN, but for all Islamic banking in Indonesia.

\section{Managerial Implications}

Management of UUS Bank BTN needs to improve profitability, taking into account the following :

1. Pressing the NPF level by improving the quality of financing problems so that the risk of bad credit can be reduced. Improved quality of financing begins by providing education and training to new employees assigned to the financing section. Furthermore, it is necessary to do good refresment including financing product features, financing rules that are incorporated into the Standard Operating Procedure (SOP), gimmick-gimmick margin promo program, as well as studies of work sectors that contribute to increasing NPF value on financing products. 
2. Increasing product variants both funding and lending and socializing to the community so that their insight into sharia also increases.

3. Capital adequacy is related to the provision of own capital which is needed to cover the risk of losses that may arise from the movement of productive assets, which is basically the majority of funds coming from third party funds or the community.

\section{RESEARCH LIMITATIONS}

The sample of the company used in this study is relatively small (only 12 periods of annual UUS Bank BTN financial statements), because the samples taken only started the UUS Bank BTN since operating. The observation period used in this study is relatively short, namely only 12 annual periods, namely from 2006 to 2017 .

\section{UPCOMING RESEARCH AGENDA}

In this study, only six independent variables and one dependent variable were used to measure profitability. Future researchers should be able to add or increase the ratio (internal and external variables) in order to contribute to the acquisition of ROA. In addition to increasing the ratio, increasing the sample will also be better for measuring the results of profitability.

\section{REFERENCE}

Abdulrahman Anam, Ousama dan A.H Fatima. (2015). Intellectual Capital and Financial Performance: of Islamic Bank. Int. J. Learning and Intellectual Capital, 12(1).

Aisyah, N. (2008). Manajemen Investasi dan Pasar Modal. Pusat Pengembangan Bahan Ajar. Universitas Mercu Buana. www//htt.mercubuana.ac.id

Atmaja, Lukas Setia. (2008). Teori dan Praktek Manajemen Keuangan. Yogyakarta. Penerbit : ANDI, Yogyakarta.

Bahri, Zainal. (2016). Pengaruh Intellectual Capital Terhadap Profitabilitas dan Produktifitas Pada Perbankan Syariah Di Indonesia. Jurnal Ilmu dan Riset Akuntansi, 5(11).

Bank Indonesia. (2005). Laporan Triwulanan Perbankan Syariah Triwulan I, II, III, IV/2005. http://www.bi.go.id/biweb/.

Brigham, Eugene F \& Loel F Houston. (2001). Fundamentals of Financial Mnajement 9thed USA: Harcount.inc

Defri. (2012). Pengaruh capital adequacy ratio, likuiditas dan efisiensi operasional terhadap profitabilitas perusahaan perbankan yang terdaftar di bursa efek indonesia. Jurnal Manajemen, 1(1), 1-18.

Dendawijaya, Lukman. (2009). Manajemen Perbankan. Jakarta : Ghalia Indonesia.

Duraj, Brunilda and Elvana Moci. (2015). Factor Influencing The Bank Profitability-Empirical Evidence From Albania. Asian Economic and Financial Review, 5(3), 483-494.

Ghozali, Imam. (2007). Aplikasi Analisis Multivariate dengan Program SPSS. Semarang : Badan Penerbit Universitas Diponegoro.

Giulio Battazzi, Angelo Secchi, and Federico Tamagni. (2008). "Productivity, Profitabilty, and Financial Performance". Oxford Journals Economics \& Social Sciences Industrial and Corporate Change, 17(4), 711-751.

Gunartin. (2015). Pengaruh Faktor Internal dan Eksternal Terhadap Profitabilitas Perbankan Syariah dan Kovensional Di Indonesia Periode Juni 2010-2013. Jurnal Akuntansi Aktual, 3(1), 91-102. 
Handayani, RR. Sri dan Agustono Dwi Rachadi. (2009). "Pengaruh Ukuran Perusahaan terhadap Manajemen Laba”. Jurnal Bisnis Dan Akuntansi, 11(1), 33-56. (Wolk dan Tearney dalam Dwiyanti, 2010). http://www.bi.go.id/ Laporan Publikasi Keuangan Bank.

Ikatan Akuntan Indonesia (IAI). (2009). Exposure Draft PSAK 19 (revisi 2009): Aset Tidak Berwujud. Pernyataan Standar Akuntansi Keuangan.

Jama'an. (2008). Pengaruh Mekanisme Corporate Governance dan Kualitas Kantor Akuntan Publik Terhadap Integritas Informasi Laporan Keuangan (Studi Pada Perusahaan Publik Di BEJ). Tesis Strata-2. Program Studi Magister Sains Akuntansi.Universitas Diponegoro, Semarang.

Kasmir. (2008). Bank dan Lembaga Keuangan Lainnya. Jakarta: PT. Rajagrafindo Persada.

Ludigdo, Unti, dan Machfoedz. (1999). Transformasi Nilai Etika dalam Rangka Peningkatan Profesionalisme Akuntan: Tinjauan atas Kurikulum Pendidikan Tinggi Akuntansi. Makalah dalam Diskusi Panel Nasional Mahasiswa Akuntansi di Unibraw: Malang.

Madhani, P. M. (2009). Resources Based View (RBV) of Competitive Advantage: An Overview. http://ssrn.com/abstract=1578704. September 2018.

Malayu S.P. Hasibuan. (2007). Manajemen Sumber Daya Manusia. Jakarta. Bumi Aksara.

Mawardi, Wisnu. (2005). Analisis Faktor-Faktor yang Mempengaruhi Kinerja Keuangan Bank Umum di Indonesia (Studi Kasus Pada Bank Umum Dengan Total Assets Kurang Dari 1 Triliun). Jurnal Bisnis Strategi, 14(1).

Muhammad. (2005). Manajemen Pembiayaan Syariah. Yogyakarta: UPP AMP YKPN.

Oskan, Nazif. Sinan Cakan and Murad Kayacan. (2016). Intellectual Capital and Finacial Performance: A Study of The Turkish Banking Sector. Borsa istanbul Review.

Pandia, Frianto. (2012). Manajemen dana dan Kesehatan Bank. Cetakan pertama. Mare, Yogyakarta.

Prasnanugraha P, Ponttie'. (2007). Analisis Pengaruh Rasio-Rasio Keuangan Terhadap Kinerja Bank Umum di Indonesia (Studi Empiris Bank-Bank Umum yang Beroperasi di Indonesia).

Pulic, A. (1998). "Measuring the performance of intellectual potential in knowledge economy". Paper presented at the 2nd McMaster Word Congress on Measuring and Managing Intellectual Capital by the Austrian Team for Intellectual Potential.

Pulic, A. (1999). "Basic information on VAICтM". available online at: www.vaicon. net. (accessed September 2018).

Pulic, A. (2000). "VAICTM - an accounting tool for IC management". Available online at: www.measuring-ip.at/Papers/ham99txt.htm (accessed September 2018).

Puspitasari, Diana. (2009). Analisis Pengaruh CAR, NPL, PDN, NIM, BOPO, LDR, dan Suku Bunga SBI Terhadap ROA (Studi Pada Bank Devisa di Indonesia Periode 2003-2007. Tesis Magister Manajemen Universitas Diponegoro.

Sawarjuwono, T., \& Kadir, A. P. (2003). Intellectual capital: Perlakuan, Pengukuran dan Pelaporan (Sebuah Library Research). Jurnal Akuntansi \& Keuangan, 5(1), 35-57.

Setiawan, Andy. (2017). Analisa Pengaruh Tingkat Kesehatan Bank Terhadap Return On Aset. Jurnal Akuntansi Dewantara, 1(2).

Shapiro, Alan C. (1991). Modern Corporate Finance. Macmillan Publishing Firm, Maxwell Macmilan International, Editor L New York. 
Siamat, Dahlan. (2005). Manajemen Lembaga Keuangan, Edisi Keempat, Badan Penerbit Fakultas Ekonomi Universitas Indonesia, Jakarta. YKPN, 2007, hlm.83

Sukarno, Kartika Wahyu dan Muhammad Syaichu. (2006). Analisa Faktor Faktor yang Mempengaruhi Kinerja Bank Umum Di Indonesia. Jurnal Studi Manajemen \& Organisasi, $3(2)$.

Susanto, A. B. (2007). Resource Based Versus Market Based. Eksekutif. No. 338: 24-25.

Sutojo, S. (2000). Strategi Manajemen Kredit Bank Umum. Jakarta: Damar Mulia Pustaka.

Syafrida, I., dan A. Abror. (2011). Faktor-Faktor Internal dan Eksternal yang Mempengaruhi Pertumbuhan Asset Perbankan Syariah di Indonesia. (online). JEB, 10(1).

Ubaidillah. (2016). Analisa Faktor-Faktor yang Mempengaruhi Profitabilitas Bank Syariah Di Indonesia. Jurnal Ekonomi Islam (Islamic Economics Journal), 4(1).

Wolk, Harry I. And Michael G. Tearney. (1997). Accounting Theory. Internasional Thompson Publishing. 